\title{
Інформаційна безпека в соціологічному контексті: до постановки проблеми
}

\author{
Проданюк Р. І., Класичний приватний університет
}

Статтю присвячено проблемі науково-теоретичної та соціально-практичної рефлексії поняття інформаційної безпеки та його співвідношення із суміжними поняттями соціології безпеки як галузевої соціологічної теорії. Автором зроблено висновок про те, що розгляд суспільства в структурному функціоналізмі передбачає розуміння інформаційної екологічності в аспекті виконання чотирьох засадничих функцій:

1) функції адаптації (adaptation), яка змістовно співпадає із виробництвом матеріальних благ та послуг шляхом використання природних ресурсів середовища. 3 точки зору інформаційної екології, визначенням якої автор цієї статті буде надалі оперувати, інформаційна екологічність економічної інформації може оцінюватись 3 точки зору її впливу на відповідні макроекономічні процеси та результати економічної життєдіяльності: обсяги виробництва та ВНП, показники безробіття, індекси цін та інфляції тощо;

2) функція ціледосягнення (goal attainment), яка залежить від культурного консенсусу, що визначається на рівні ідеології. Це випливає з того, що консенсус між ключовими політичними акторами досягається, передусім, на платформі відповідної ідеології. В ідеології відповідні суб'єкти можуть впроваджувати стандарти оцінювання інформації з точки зору її інформаційної безпечності / небезпечності;

3) Функція інтеграції (integration), котра забезпечується дотриманням інформаційної екологічності в сфері соціальної моралі та права. Соціальна мораль є складником культурної системи, в якій впроваджуються критерії вирізнення належного / неналежного. 3 іншого боку, право дозволяє формалізувати зазначені критерії у вигляді кодексів стандартизованих поведінкових приписів (прескрипцій), які уможливлюють уніфікацію соціальної поведінки. Наголошено, що від інформаційної безпеки залежить як стан моральної, так і правової регуляції соціальної поведінки;

4) функція підтримання ціннісних зразків (latency), яка передбачає збереження і підтримання основних цінностей суспільства. Автором констатовано, що для такого збереження і підтримання є необхідним встановлення вищих цензурних фільтрів аксіосфери, проходження інформації через які дає можливість ії відтестовування на предмет потнеційної користності / шкідливості для інших соціальних підсистем, інституцій, спільнот та осіб.

Ключові слова: інформаційна безпека; інформаційна екологія; інформаційна екологічність; інформаційна шкідливість; соціальна гігієна; соціальний контроль

\section{Information security in the sociological context: before the problem is raised}

\section{Prodaniuk R. I., Classic Private University}

The article is devoted to the problem of scientific-theoretical and socio-practical reflection of the notion of information security and its relationship with the related concepts of sociology of security as a branch sociological theory. The author concludes that the consideration of society in structural functionalism involves an understanding of environmental information in the aspect of the implementation of four fundamental functions:

1) adaptation, which coincides with the production of material goods and services through the use of natural resources of the environment. From the point of view of information ecology, the definition of which the author of this article will continue to operate, the environmental ecology of economic information can be estimated from the point of view of its impact on relevant macroeconomic processes and results of economic activity: output and GNP, unemployment rates, price indices and inflation, etc.;

2) the function of goal-achievement depends on the cultural consensus that is determined at the level of ideology. This follows from the fact that the consensus between key political actors is reached primarily on the platform of the corresponding ideology. In ideology, relevant actors can implement standards for assessing information in terms of its information safety / security;

3) The function of integration is ensured by adherence to environmental information in the field of social morality and law. Social morals are an integral part of the cultural system, in which the criteria for distinguishing the proper / improper ones are introduced. On the other hand, the right allows to formalize the specified criteria in the form of codes of standardized behavioral prescriptions (prescriptions) that allow for the unification of social behavior. It is emphasized that from the information security depends both the state of moral and legal regulation of social behavior;

4) the function of maintaining value protocols (latency), which presupposes the preservation and maintenance of the basic values of society. The author states that for such preservation and maintenance, it is necessary to establish higher censorial axioplast filters, the passage of information through which it is possible to validate it for the subject of its peculiar use / harm to other social subsystems, institutions, communities and individuals.

Keywords: information security; information ecology; informational ecology; information harmfulness; social hygiene; social control 


\title{
Информационная безопасность в социологическом контексте: к постановке проблемы
}

\author{
Проданюк Р. И., Классический приватный университет
}

Статья посвящена проблеме научно-теоретического и социально-практического осмысления понятия информационной безопасности и его взаимосвязи с связанными понятиями социологии безопасности как отраслевой социологической теории. Автор приходит к выводу, что рассмотрение общества в структурном функционализме предполагает понимание экологической информации в аспекте реализации четырех основных функций:

1) адаптация, которая совпадает с производством материальных благ и услуг за счет использования природных ресурсов окружающей среды. С точки зрения информационной экологии, определение, над которым автор этой статьи будет продолжать работать, экология экономической информации может быть оценена с точки зрения ее воздействия на соответствующие макроэкономические процессы и результаты экономической деятельности: объем производства и ВНП, уровень безработицы, индексы цен и инфляция и т. д.;

2) функция достижения цели, которая зависит от культурного консенсуса, определяемого на уровне идеологии. Это следует из того факта, что консенсус между ключевыми политическими субъектами достигается прежде всего на платформе соответствующей идеологии. В идеологии соответствующие субъекты могут внедрять стандарты для оценки информации с точки зрения ее информационной опасности / безопасности;

3) Функция интеграции, которая обеспечивается соблюдением экологичности информации в области социальной морали и права. Социальная мораль является неотъемлемой частью культурной системы, в которой вводятся критерии для определения надлежащего / неправильного. С другой стороны, право позволяет формализовать указанные критерии в виде кодов стандартизованных поведенческих предписаний (прескрипций), которые позволяют унифицировать социальное поведение. Подчеркивается, что от информационной безопасности зависит состояние морально-правового регулирования социального поведения;

4) функция поддержания значений (латентность), которая предполагает сохранение и поддержание основных ценностей общества. Автор утверждает, что для такого сохранения и поддержания необходимо создать более ценные аксиопластические фильтры, передачу информации, с помощью которой можно проверить ее на предмет ее потенциальной полезности / вредности другим социальным подсистемам, учреждениям, сообществам и физическим лицам.

Ключевые слова: информационная безопасность; информационная экология; информационная экология; информационная вредоносность; социальная гигиена; социальный контроль

\section{Постановка проблеми.}

ростання глобальної залежності в поєд-

3 нанні 3 інформатизацією і можливостями новітніх інформаційних технологій детермінують виникнення не лише зручностей i зростання адаптивності людства, але і виникнення нових загроз та проблем інформаційної безпеки суспільства. Унаочнення означених загроз відбувається на тлі формування глобальної інформаційної екосистеми із притаманними їй особливостями підтримання інформаційної екології.

Інформаційний ресурс вже давно перестав бути периферійним інструментом простого задоволення потреб технічної зручності, перетворившись на чинник геополітичного домінування суспільств різних типів у глобальному інформаційному просторі. Немає сенсу доводити, що майбутнє зазначених суспільств у їх взаємному інформаційному протистоянні в інформаційній екосистемі залежатиме від гарантування інформаційної екологічності та безпечності інформаційного простору.

Наукова точка зору на інформацію як капітал найвищого ступеня важливості може вважатися, як мінімум, важко спростовною. Ресурси соціально-політичної впливовості дедалі більше залежать від інформаційних та соціокультурних складників інформаційного просування того чи іншого суспільства.

Це інформаційне просування може стосувати- ся популяризації власної релігійної моралі, світогляду та цінностей, можливостей експорту інтелектуального капіталу з інших країн, поширення власної мови тощо. Тому будь-яке сучасне суспільство не може обійти використання інформаційної екології як новітнього напрямку соціологічних досліджень, який є спрямованим на обгрунтування теорії та практик забезпечення інформаційної рівноваги / збалансованості в системі культури, соціальних інститутів, соціальних груп та осіб.

Відома в наукових та медіаколах теорія так званої «м'якої сили» перш за все орієнтована на обгрунтування так званої тонкої (інформаційно-духовної) зброї у стратегіях суперництва і протиборства суспільств, у реалізації утвердження їх символічних універсумів та інституцій влади, підтримувати процеси адекватного групоутворення та смислопродукування, на що звертає увагу в своїх працях Ю. Романенко [9-12].

Автор констатує, що лідерство та гегемонія у сфері смислопродукування стають пріоритетними в конкуренції суспільств у контексті боротьби за ідентичності. Переважання інформаційної безпеки набуває все більше підстав.

За умови підвищення інтелектуалізованості та зростання значущості інформаційної безпеки відбувається процес зміщення центрів влади в суспільствах від військової, економічної, політичної до культурної та інформаційно-психологічної, на 
що вказує у своїх працях А. Тофлер, і думку якого наводить Р. Капурро [15]. Ця своєрідна соціальна еволюція стає позначником XXI століття. Оскільки саме в зазначену епоху задоволення потреб суспільств у домінуванні здійснюється за допомогою впливів не стільки в сфері матерії та енергії, скільки у сфері інформації.

Аналіз досліджень та публікацій.

Джерела, в яких є дослідженою інформаційна безпека, можуть бути класифіковані на три базові групи:

1) група джерел, у яких інформаційна безпека розглядається переважно в ракурсі інформаційно-комунікаційних (комп'ютерних) технологій та аналізується під кутом зору вирізнення небезпек суто технічного гатунку. Так, С. Андрєєв веде мову про інформаційну безпеку як про «захищеність інформації та відповідної інфраструктури від випадкових або навмисних впливів, які супроводжуються нанесенням шкоди власникам або користувачам інформації та ... гарантують забезпечення конфіденційності, цілісності та доступності інформації. Метою захисту інформації, на думку автора, є мінімізація втрат, викликаних порушенням цілісності або конфіденційності даних, а також їх недоступності для споживачів» [2, c. 79-80]. 2) група джерел, у яких презентовано доктринально-політичне та юридичне розуміння інформаційної безпеки в іiі зв'язку із національною та державною безпекою, з одного боку, та інформаційно-психологічною безпекою - 3 іншого $[1$, с. $43-47]$.

Прихильники цієї точки зору, наприклад, В. Остроухов та В. Петрик, вважають, що «інформаційна безпека - це стан захищеності об'єкта (особистості, суспільства, держави, інформаційно-технічної інфраструктури), при якому досягається його нормальне функціонування незалежно від внутрішніх і зовнішніх інформаційних впливів» [6, с. 22-23].

Надалі автори розрізняють інформаційну безпеку особи, держави і суспільства. Інформаційна безпека особи, по суті, зводиться до психофізичного здоров'я та захищеності «людини від деструктивних інформаційних впливів, який призводить до неадекватного сприйняття нею дійсності та (або) погіршення їі фізичного стану» [6, c. 24-25]. В контексті соціологічного розуміння інформаційної безпеки йдеться про правильну налаштованість соціального сприйняття на побудову невикривленої картини соціального світу.

Інформаційну безпеку суспільства автори розглядають iз приховано-юридичним ухилом, наголошуючи на безперешкодності «реалізації суспільством та окремими його членами своїх конституційних прав, пов'язаних із можливістю вільного одержання, створення й поширення інформації, а також ступінь їхнього захисту від деструктивного інформаційного впливу» [6, с. 24$25]$.
Водночас, у розумінні інформаційної безпеки держави автори схиляються до інформаційно-мілітарного іiі тлумачення, послуговуючись для опису загроз, що можуть виникати як складники цього різновиду безпеки, кримінологічним та військово-польовим тезаурусом («спеціальні інформаційні операції», «акти зовнішньої інформаційної агресії», «інформаційний тероризм», «незаконне зняття інформації за допомогою спеціальних технічних засобів», «комп'ютерні злочини та інший деструктивний інформаційний вплив») [6, с. 24-25].

3) група джерел, у яких презентовано соціологічне розуміння інформаційної безпеки як складника культурної та соціальної безпеки. Доволі обмеженою є кількість праць в українській соціології, яка була б пов'язана із цією тематикою. До зазначених авторів можна зарахувати О. Єрьоміна, М. Мізінцєву, О. Парахонського, В. Шапцева, О Яницького. Серед англомовних авторів проблему в дотичному до соціології контексті досліджували I. Капурро, Т. Девенпорт, I. Мальтора [3-4; 7, с. 8; 8 , с. $88-89 ; 13$, с. $33-34 ; 14 ; 15$, с. $122-139 ; 16$, с. 272].

Так, В. Ніколаєвський у своїх публікаціях 3 теорії соціальної безпеки інтерпретує інформаційну безпеку, поруч із політичною, економічною, військовою, релігійною, ідеологічною та культурною безпекою як систему інструментів мінімізації соціального макростресу.

Автор спирається на теорію соціального макростресу Готшлаха i Бенке, які розглядали соціальний макрострес як генералізований показник певної кількості синхронізованих подразників інформаційного простору, поширення яких призводить до порушення нормального функціонування соціальних інститутів. Зазначений показник розглядається авторами у зв' язку із процесом глобалізації, який несе 3 собою відповідні інформаційні ризики через обставини виникнення і поширення електронних комунікацій та віртуальної інфраструктури.

А оскільки глобалізація стає можливою як процес, який розгортається в умовах інформаційного суспільства, то зазначений напрямок досліджень виходить на соціологію глобалізації та соціологію інформаційного суспільства із відповідними парадигмами та теоретичними схемами зв'язку між інформаційною безпекою, інформаційним суспільством та глобалізаційними зрушеннями в архітектоніці інформаційного простору на тлі діяльності 3МI та електронних комунікацій.

В усіх зазначених групах джерел так чи інакше фігурують посилання на відповідні нормативно-правові акти, в яких є представленим офіційно-державне розуміння інформаційної безпеки, в якому робиться наголос на стані захищеності відповідних політичних інтересів державно-організованих спільнот. Взагалі доволі слушною $є$ пропозиція В. Ніколаєвського щодо соціальної 
сек'юритології як альтернативи звичайній соціології безпеки. Сам автор вважає, що соціальна сек'юритологія охоплювала б вивчення як соціальних інституцій, спільнот, культури суспільства, так і технічних, біологічних та інших (несоціальних) об'єктів [5, с. 89-96].

Метою дослідження $\epsilon$ побудова робочого визначення інформаційної безпеки в соціологічному аспекті та окреслення кола соціальних груп та інституцій, які реалізують інформаційну безпеку та впливають на неї. Завданнями статті у зв'язку iз визначеною метою $є$ : а) проаналізувати ключові теоретико-методологічні підходи до розуміння інформаційної безпеки як соціального інституту; б) визначити соціальні групи та інституції, включені в процеси підтримання та захисту інформаційної безпеки.

Невизначена наукова проблема, якій присвячено статтю. Статтю присвячено проблемі науково-теоретичної та соціально-практичної рефлексії поняття інформаційної безпеки та його співвідношення із суміжними поняттями соціології безпеки як галузевої соціологічної теорії.

Виклад основного матеріалу.

У автора цієї статті є достатні підстави погодитись із В. Ніколаєвським в тому відношенні, що соціальна безпека $є$ механізмом контролінгу соціального гомеостазу [5, с. 89-96]. Автор формулює таке визначення, спираючись на теорію структурного функціоналізму Т. Парсонса [13-18].

Парсонс, як відомо, характеризував консенсус як передумову стабільності аксіосфери культурної системи як управлінської системи стосовно соціальної та соцієтальної систем. Важко заперечувати те, що інституціоналізація зразків ціннісних орієнтацій у соціальній системі залежить від соціологічної спільноти професіоналів.

Розгляд суспільства в структурному функціоналізмі передбачає розуміння інформаційної екологічності в аспекті виконання чотирьох засадничих функцій:

1) функції адаптації (adaptation), яка змістовно співпадає із виробництвом матеріальних благ та послуг шляхом використання природних ресурсів середовища [22, с. 44]. 3 точки зору інформаційної екології, визначенням якої автор цієї статті буде надалі оперувати, інформаційна екологічність економічної інформації може оцінюватись 3 точки зору їі впливу на відповідні макроекономічні процеси та результати економічної життєдіяльності: обсяги виробництва та ВНП, показники безробіття, індекси цін та інфляції тощо.

2) функція ціледосягнення (goal attainment), яка залежить від культурного консенсусу, що визначається на рівні ідеології. Це випливає 3 того, що консенсус між ключовими політичними акторами досягається, передусім, на платформі відповідної ідеології. В ідеології відповідні суб'єкти можуть впроваджувати стандарти оцінювання інформації з точки зору іiі інформаційної безпечності / небезпечності.

Можна погодитися з точкою зору Ю. Романенка [11, с. 78-79] 3 приводу того, що вищі структури аксіосфери, які автор називає вищими структурами культурної системи, або ж вищим регістром смислоцензурування, забезпечують основу для первинної оцінки будь-якої інформації, яка циркулює в інформаційному просторі.

3) Функція інтеграції (integration) [21, с.63-64], яка забезпечується дотриманням інформаційної екологічності в сфері соціальної моралі та права. Соціальна мораль є складником культурної системи, в якій упроваджуються критерії вирізнення належного / неналежного. 3 іншого боку, право дозволяє формалізувати зазначені критерії у вигляді кодексів стандартизованих поведінкових приписів (прескрипцій), які уможливлюють уніфікацію соціальної поведінки. В кінцевому підсумку від інформаційної безпеки залежить як стан моральної, так і правової регуляції соціальної поведінки.

4) функція підтримання ціннісних зразків (latency) [20, с. 119-130], яка передбачає збереження i підтримання засадничих ціннісних універсалій суспільства. Для такого збереження i підтримання $є$ необхідним встановлення вищих цензурних фільтрів аксіосфери, проходження інформації через які дає можливість ії відтестовування на предмет іï потенційної корисності / шкідливості для інших соціальних підсистем, інституцій, спільнот та осіб.

Коли аксіосфера є не просто існуючою, але інституціоналізованою i структуро-векторизуючою щодо соціальної поведінки, то соціальна і соцієтальна системи досягають стану безпеки або ж «соціальної рівноваги».

Механізмами забезпечення соціальної рівноваги є:

a) соціалізація як процес транслювання соціальних цінностей в міжгенераційному просторі (інституціями соціалізації є сім'я та освіта);

б) соціальний контроль як сукупність інструментів підтримання відповідності між поведінковими моделями соціальної поведінки та ціннісно-нормативними зразками, створеними в культурній системі.

У відповідності із цим розумінням інформаційна безпека може розглядатись як одна iз соціальних інституцій контролю за підтриманням інформаційної рівноваги, функція якої полягає в підтриманні екологічності інформаційного простору.

Стан інформаційної екологічності може розглядатись як такий стан, в якому система підтримує контроль над суб'єктами та процесами, які можуть реально або потенційно здійснити порушення інформаційної рівноваги шляхом їх впливу на ті чи інші функції соціальної системи через інформаційний простір суспільства.

О. П. Парахонський вважає, що предметне поле інформаційної екології охоплює наступні те- 
матичні блоки критерійної оцінки: а) оцінка якості інформації; б) оцінка управління інформацією; в) оцінка продуктів інформації; г) оцінка діяльності інформаційних служб; д) оцінка інформаційної цінності (цінності інформації); є) оцінка інформаційних потреб; ж) оцінка інформаційної відповідальності [8, с. 88-89].

Автор розглядає в якості ознаки порушення інформаційної екологічності «невідповідність між запланованим (використанням) і реальним використанням інформації, коли мають місце порушення в сфері інформаційної екології. У зв'язку 3 цим автором запропоновано «розвивати інформаційні стандарти, щоб розрізняти зв'язки між інформацією, користувачами інформацією і використанням інформації» [8, с. 88-89].

Враховуючи те, що первинні стандарти оцінювання інформації створюють суб'єкти аксіосфери, які, на думку Ю. Романенка, є продуцентами ціннісного знання, то стандарти оцінки інформаційної екологічності того чи іншого інформаційного процесу чи продукту мають здійснювати саме ці суб'єкти в контексті відповідності / невідповідності їх певним стандартам ціннісного знання [9, c. 100-101].

О. П. Парахонський пропонує оцінювати інформацію за такими шістьма властивостями інформації: 1) предмет інформації; 2) фокус охоплення інформації; 3) контекст подання інформації; 4) час подання інформації; 5) джерело інформації; 6) якість інформації [8, с. 88-89].

Висновки. Таким чином, оцінка інформаційної екологічності як предмет дослідження інформаційної екології передбачає оперування поняттями «інформаційні коди», «інформаційне середовище», «екологічне мислення» 3 акцентуванням взаємозв'язків адаптаційної, ціледосягальної, інтеграційної та ціннісно-підтримуючої підсистем в інформаційному просторі.

Проблеми 3 інформаційною екологічністю виникають саме в інформаційному суспільстві, інформаційний простір якого $є$ перенасиченим слабко-структурованою інформацією. I саме ця інформація може бути оцінена як забруднююча щодо інформаційного середовища та така, що порушує його інформаційну екологічність, а отже й інформаційну безпеку.

Підкреслюється, що мірою екологічної якості інформації можуть бути ії соціальний характер, лінгвістичні та історичний аспекти. Ці аспекти можуть сприяти розумінню концепції інформаційного забруднення. Таким чином, інформацій- на екологія $є$ науковим напрямком соціології та соціотехнологій, предметом дослідження яких $є$ закономірності впливу інформації на формування і функціонування особи, соціальних спільнот і інституцій, на індивідуальні та соціально-групові відносини $з$ інформаційним середовищем та різноманітні інформаційні взаємодії $[7$, с. $8 ; 8$, с. 88 89].

Циркулювання фрагментованої, токсичної, неекологічної інформації може мати шерег негативних наслідків впливу на індивідів та соціальні спільноти. У зв'язку з цим самостійної оцінки потребує впровадження таких критеріїв оцінки інформації, як «інформаційна токсичність» «фрагментованість / генералізованість», «сподіваність / несподіваність», «ціннісна релевантність / нерелевантність» тощо.

Наслідками проникнення «забруднюючої» («токсичної») інформації в інформаційний простір суспільства може ставати дезорганізація в роботі різних соціальних інститутів, виникнення різних стрес-факторів, які імпліцитно спричиняють підвищення психоемоційного напруження та зростання статистичних показників захворюваності в серцево-судинному, нервовому, травному, імунно-дефіцитному, онкологічному сегментах. «Токсична» інформація у фінансово-економічній сфері впливає на кількість закритих підприємств та банків, виникнення зон спустошення в сільському господарстві, дефіциту робочої сили, непродуктивної міграції тощо.

Інформаційні токсини можуть впливати також на виникнення девіацій та інвалідизуючих психічних розладів (тривожність, депресія, суїцидальна поведінка тощо).

Толерування щодо інформаційних токсинів у релігійній та ідеологічній сферах може спричинити порушення міжкультурного консенсусу та ініціювати ідеологічні конфлікти, 3 яких логічно випливатимуть расові, міжетнічні та міжнаціональні, міжконфесійні конфлікти різної генези.

Інформаційна екологія може розглядатись як частина іншого новітнього напрямку соціологічного теоретизування та соціальних практик - культурної та соціальної гігієни. Культурна та соціальна гігієна можуть розглядатися як соціотехнологічні напрямки дослідження, предметом яких може виступати розробка відповідних стандартів забезпечення рівноваги між аксіосферою культурної системи, соціальною та соцієтальною системами шляхом селекції, фільтрації. 


\section{БІБІЛІОГРАФІЧНІ ПОСИЛАННЯ}

1. Аносов В. Д. Проблемы обеспечения информационно-психологической безопасности / В. Д. Аносов, В. Лепский, А. А. Стрельцов // Информационное общество. - 1997. - № 4-6. - С. 43-47.

2. Андреев С. С. Информационная культура: уровень содержания духовных ценностей / С. С. Андреев // Социально-политический журнал. - 1998. - № 2. - С. 79-112.

3. Еремин А. Л. Ноогенез и теория интеллекта / А. Л. Еремин. - Краснодар: СовКуб, 2005. - 356 с.

4. Мизинцева М. Ф. Информационная экология: монография / М. Ф. Мизинцева, Л. М. Королева, В. В. Бондарь. М.: Изд-во «Альта», 2000.- 231 с.

5. Ніколаєвський В. Соціальна безпека: до визначення поняття / В. Ніколаєвський, О. Гужва // Вісник ХНУ ім. В. Каразіна. Серія «Соціологія». - 2011. - № 3. - С. 89-96.

6. Петрик В. М. Соціально-правові основи інформаційної безпеки: Навчальний посібник / В. М. Петрик, А. М. Кузьменко, В. В. Остроухов та ін.; за ред. В. В. Остроухова. - Київ: Росава, 2007. - 496 с.

7. Парахонский А. П. Проблемы информационной экологии в ноосфере / А. П. Парахонский, А. Л. Еремин // Международный журнал прикладных и фундаментальных исследований. - 2009. - № 7. - С. 88-90.

8. Парахонский А. П. Информационная экология / А. П. Парахонский // Успехи современного естествознания. 2011. - № 11. - С. 88-89.

9. Романенко Ю. В. Смислопродукування в соціальних системах. Монографія / Ю. В. Романенко. - Київ: Е та Е, 2005. - 347c.

10. Романенко Ю. В. Сучасні психотехнології. Навчальний посібник для студентів відділення «Міжнародна інформація» / Ю. В. Романенко. - Київ: вид-во ДУІКТ, 2008. - 82 с.

11. Романенко Ю. В. Соціалізація особи: метапрограмний та психотехнологічний аспекти / Ю. В. Романенко. Київ: вид-во ДУІКТ, 2007. - 463 с.

12. Романенко Ю. В. Механізми символічної інтеракції в комунікаціях, політиці, мистецтві: візуально-аналітичний та соціо-символічний аспекти. Монографія / Ю. В. Романенко, Л. О. Скідін. - Київ: вид-во ДУІКТ, 2011. $301 \mathrm{c}$.

13. Шапцев В. А. Информационная экология информационного общества. Материалы семинара «Информационная кампания по пропаганде экологических знаний в информационном обществе» / В. А. Шапцев. - М.: Высший химический колледж РАН, 2003. - С. 33-44.

14. Яницкий О. Н. Экологические катастрофы: структурно-функциональный анализ / О. Н. Яницкий // Официальный сайт ИС РАН. - 2013. - 258 с. - Режим доступа: http://www.isras.ru/publ.html?id=2794

15. Capurro R. Towards an Information Ecology / R. Capurro. - London: Taylor Graham, 1990. - P. 122-139.

16. Davenport T. Information Ecology: Mastering the Information and Knowledge / T. Davenport. - London: Johnny Carpenter, 1996. -790 p.

17. Malhotra Y. Knowledge Management for Organizational White-Waters: An Ecological Framework / Y. Malhotra // Published in Knowledge Management. - 1999. - P. 18-21. - Retrieved from: http://brint.org/WhiteWaters.pdf

18. Parsons T. Some Reflections on the Place of Force in Social Process / T. Parsons; H. Eckstei (ed.) // Internal War: Basic Problems and Approaches. - New-York: The Free Press of Glencoe, 1964. - 209 p.

19. Parsons T. The Political Aspect of Social Structure and Process / T. Parsons; D. Easton (ed.) // Varieties of Political Theory. - Englewood Cliffs: Prentice-Hall, 1966. - 433p.

20. Parsons T. Interaction / T. Parsons // The International Encyclopedia of Social Sciences. - New-York: Glencoe The Free Press, 1968. - Vol. 7. - 654 p.

21. Parsons T. Family, Socialization and Interaction Process / T. Parsons, R. F. Bales. - New-York: Glencoe The Free Press, 1955. -608 p.

22. Parsons T. Economy and Society / T. Parsons, N. Smelser. - New-York: Glencoe The Free Press, 1956. - 412p.

23. Parsons T. Toward a General Theory of Action / T. Parsons et al. (eds.). - Cambridge: Harvard University Press, 1951. $-590 \mathrm{p}$.

\section{REFERENCES}

1. Anosov, V.D. (1997). Problemy obespecheniya informatsionno-psikhologicheskoy bezopasnosti [Problems of Ensuring Informational and Psychological Security]. Informatsionnoye obshchestvo, 4-6, 43-47 [in Russian].

2. Andreyev, S.S. (1998). Informatsionnaya kul'tura: uroven' soderzhaniya dukhovnykh tsennostey [Information culture: the level of content of spiritual values]. Sotsial'no-politicheskiy zhurnal, 2, 79-112 [in Russian].

3. Yeremin, A.L. (2005). Noogenez i teoriya intellekta [Noogenesis and Theory of Intelligence]. Krasnodar: SovKub [in Russian].

4. Mizintseva, M.F., Koroleva, L.M., \& Bondar', V.V. (2000). Informatsionnaya ekologiya: monografiya [Information Ecology]. Moscow: Izd-vo «Al’ta» [in Russian].

5. Nikolaevs'kiy, V., \& Guzhva, O. (2011). Sotsíal'na bezpeka: do viznachennya ponyattya [Social security: before the viznachennya ponimatya]. Vísnik HNU ím. V. Karazína. Sotsíologíya. - 2011, 3, 89-96 [in Ukrainian].

6. Petrik, V.M., Kuz'menko, A.M., \& Ostroukhov, V.V. et al. (2007). Sotsíal'no-pravoví osnovi ínformatsíynoî bezpeki [Socio-legal bases of information security]. V.V. Ostroukhov (eds.) - Kyiv: Rosava, 2007 [in Ukrainian].

7. Parakhonskiy, A.P., \& Yeremin, A.L. (2009). Problemy informatsionnoy ekologii v noosfere [Problems of information ecology in the noosphere]. Mezhdunarodnyy zhurnal prikladnykh i fundamental'nykh issledovaniy, 7, 88-90 [in Russian]. 8. Parakhonskiy, A.P. (2011). Informatsionnaya ekologiya [Information Ecology]. Uspekhi sovremennogo 
yestestvoznaniya, 11, 88-89 [in Russian].

9. Romanenko, Yu.V. (2005). Smisloprodukuvannya v sotsíal'nikh sistemakh [Meaning production in social systems]. Kyiv: Ye ta Ye [in Ukrainian].

10. Romanenko, Yu.V. (2008). Suchasni psykhotekhnologii [Modern psychotechnologies]. Kyiv: vid-vo DUÍKT [in Ukrainian].

11. Romanenko, Yu.V. (2007). Sotsializatsiia osoby: metaprohramnyi ta psykhotekhnolohichnyi aspekty [Socialization of the person: metaprogramm and psychotechnological aspects]. Kyiv: vid-vo DUÍKT [in Ukrainian].

12. Romanenko, Yu.V., \& Skídín, L.O. (2011). Mekhanizmy symvolichnoi interaktsii v komunikatsiiakh, politytsi, mystetstvi: vizualno-analitychnyi ta sotsio-symvolichnyi aspekty [Mechanisms of symbolic interaction in communications, politics, art: visual-analytical and socio-symbolic aspects]. Kyiv: vid-vo DUíKT [in Ukrainian].

13. Shaptsev, V.A. (2003). Informatsionnaya ekologiya informatsionnogo obshchestva. [Information Ecology of the Information Society]. Informatsionnaya kampaniya po propagande ekologicheskikh znaniy $\mathrm{v}$ informatsionnom obshchestve: Materialy seminara - Information campaign on the promotion of ecological knowledge in the information society: Proceedings of the seminar. Moscow: Vysshiy khimicheskiy kolledzh RAN, 33-44 [in Russian].

14. Yanitskiy, O.N. (2013). Ekologicheskiye katastrofy: strukturno-funktsional'nyy analiz [Ecological catastrophes: structural-functional analysis]. Ofitsial'nyy sayt IS RAN. Retrieved from: http://www.isras.ru/publ.html?id=2794 [in Russian].

15. Capurro, R. (1990). Towards an Information Ecology. London: Taylor Graham, 122-139.

16. Davenport, T. (1996). Information Ecology: Mastering the Information and Knowledge. London: Johnny Carpenter.

17. Malhotra, Y. (1999). Knowledge Management for Organizational White-Waters: An Ecological Framework. Published in Knowledge Management, 18-21. Retrieved from: http://brint.org/WhiteWaters.pdf

18. Parsons, T. (1964). Some Reflections on the Place of Force in Social Process.. Internal War: Basic Problems and Approaches. H. Eckstei (ed.). New-York: The Free Press of Glencoe.

19. Parsons, T. (1966). The Political Aspect of Social Structure and Process. Varieties of Political Theory. D. Easton (ed.). Englewood Cliffs: Prentice-Hall.

20. Parsons, T. (1968). Interaction. The International Encyclopedia of Social Sciences.. New-York: Glencoe The Free Press, Vol. 7.

21. Parsons, T., \& Bales, R.F. (1955). Family, Socialization and Interaction Process. New-York: Glencoe The Free Press

22. Parsons, T., \& Smelser, N. (1956). Economy and Society. New-York: Glencoe The Free Press.

23. Parsons, T. (1951). Toward a General Theory of Action. Cambridge: Harvard University Press.

\section{Проданюк Роман Іванович}

Аспірант

Класичний приватний університет

69000, Запоріжжя, вул. Жуковського, 70Б

\section{Prodaniuk Roman I.}

Postgraduate student

Classic Private University

70B, Zhukovs'kogo Str., 69000, Zaporizhzhya, Ukraine

Email: romanprodaniuk@gmail.com

Цитування: Проданюк Р. І. Інформаційна безпека в соціологічному контексті: до постановки проблеми // Науково-теоретичний альманах «Грані». - 2018. - Т. 21. - № 4. - С. 84-90.

Citation: Prodaniuk, R.I. (2018). Informacijna bezpeka v sociologichnomu konteksti: do postanovky problemy [Information security in the sociological context: before the problem is raised]. Scientific and theoretical almanac «Grani», 21(4), 84-90. 